\title{
The Role of Founder-CEO, Human Capital and Legitimacy in Venture Capital Financing in China's P2P Lending Industry
}

\author{
Hui Zheng ${ }^{1}{ }^{1}$, Xuexu Piao $^{2}$ and Sangmoon Park ${ }^{1, *}$ \\ 1 Department of Business Administration, College of Business Administration, Kangwon National University, \\ Chuncheon 24341, Korea; zh.wendy1109@kangwon.ac.kr \\ 2 School of Management, Jiangsu University, Zhenjiang 212013, China; suhlwook@gmail.com \\ * Correspondence: venture@kangwon.ac.kr
}

check for updates

Citation: Zheng, H.; Piao, X.; Park, S. The Role of Founder-CEO, Human Capital and Legitimacy in Venture Capital Financing in China's P2P Lending Industry. Sustainability 2021, 13, 1625. https://doi.org/10.3390/ su13041625

Academic Editors: Marc A. Rosen and Chia-Lin Chang

Received: 23 November 2020

Accepted: 29 January 2021

Published: 3 February 2021

Publisher's Note: MDPI stays neutral with regard to jurisdictional claims in published maps and institutional affiliations.

Copyright: (C) 2021 by the authors Licensee MDPI, Basel, Switzerland. This article is an open access article distributed under the terms and conditions of the Creative Commons Attribution (CC BY) license (https:/ / creativecommons.org/licenses/by/ $4.0 /)$.

\begin{abstract}
The paper investigates factors to financing from venture capital (VC) in the Peer to Peer (P2P) lending industry of China. We focus on the signal effects of founder-CEOs, human capital, and legitimacy on venture capital investment. An important issue for entrepreneurship research is how to reduce $t$ information asymmetry between entrepreneurs and potential investors. This paper builds on the signal theory to explain how new ventures can signal their qualities and promising businesses to potential investors to obtain external investment. By using a total of 2388 new ventures in China's P2P lending industry, this paper analyzed the effects of factors on VC investment. We found that the founder-CEO status and the legitimacy of third-party signals are crucial to obtain the support of venture capital. We found that the CEO's international experience has positively significant on VC financing, but the industry experience of CEOs is insignificant to get VC investment. The results indicate that new venture should pay more attention to build the ways of signaling and legitimacy of new venture to get external resource providers.
\end{abstract}

Keywords: P2P lending; China; venture capital; founder-CEO; human capital; legitimacy

\section{Introduction}

Entrepreneurs have profoundly changed the competitive environments in traditional industries and also created new industries with innovative products and services. Due to the development of digitization, there are many opportunities for entrepreneurs to create new businesses in different sectors including finance industries. A group of new business, financial technology (fintech), have been developed by new ventures and entrepreneurs who innovating new business models with digital technologies in financial industries [1] Peer-to-Peer (P2P) lending is one of the fintech businesses where lenders and borrowers are directly matched through online services so as to lend money to individuals and businesses [2]. As Chinese P2P Lending industries have grown rapidly in last decade and became the largest country in the global P2P Lending market, China's total volume of the P2P consumer lending in 2018 was USD 163 billion from USD 52 billion in 2016, compared to the market size of US's P2P consumer lending where the total volume was USD 25 billion in 2018 and USD 21 billion in 2016 [3]. As most new ventures have financial constraints, start-ups in the Chinese P2P lending sector have limited internal resources and require outside financial support for survival and development in highly competitive and emerging market [1,4]. A particular point of interest for us is to understand how new ventures communicate their quality to venture capitalists (VCs), as the latter are outside investors under conditions of information asymmetry and since the venture capital is among the most important sources of support for new ventures with a high growth potential. For the emerging fintech industry, such as the P2P lending industry, how should entrepreneurs stand out from numerous competitors to obtain VC financing?

Much attention has been given by researchers to signaling strategies being used by later-stage startups which are more commonly present. However, this paper furthers the 
idea that it is not enough to focus on late-stage startups in mature industries, and we should also focus on early stage startups present in emerging industries. According to the information already present with regards to the VCs' investment decisions, importance is placed upon the experience and skills of the top management teams of the ventures when dealing with financial commitments. Still, the impact that the CEOs' characteristics have on the team has not been extensively examined in current existing literature. Although Patzelt [5] claimed that the CEOs' education and experience signals can help investors judge new ventures' growth and performance potential in the future, but his focus was on high-technology industries.

In considering the market valuation of new ventures, particularly ones nearing IPO, a special amount of attention has been devoted by scholars in regards to the part played by third-party affiliates as signals of enhancement [6]. Third-party signals have played a positive role in the listed companies, and helpings enterprises to achieve success at the IPO stage. Be that as it may, little attention has been paid in the current literature to how the third-party signals impacts the VC financing of the early stage startups decisions.

First, our study combined signaling theory [7] and human capital theory [8] to explore the important role of CEO competence in the financial investment of venture capital to fintech new ventures. We debate that the CEOs' human capital and founder status show new ventures' potential for future growth [9], and thus VCs are more willing to invest in new venture managed by CEOs with a wealth of human capital and founder status [5]. Second, the signals are established amongst their new ventures' relationship with thirdparties. Institutions such as these change the identities and bolster the legitimacy needed by selected startups through tangible and symbolic resources [10].

Our findings contribute in several ways. First, our study proves that a CEO's characteristics positively influence VC financing in the emerging industry. Specifically, CEO founder status can reflect the authenticity of entrepreneurs in emerging industries with high information asymmetry. Although the CEO's industry experience does not influence VC financing, the CEO's international experience can embody his or her ability to deal with market changes and the potential of enterprise development. Second, we have expanded the sources of third-party signals to include industry associations and ICP. The difference between industry association and ICP is that the former is a self-organized group institution among enterprises in the industry, whose purpose is to supervise each other among enterprises; ICP is a certification recognized by the government. Entrepreneurs can demonstrate their new venture's high quality to investors through such signals.

In the coming section, we will expand upon our theory and hypotheses. We will then present a description of the data and methodology that were used before presenting our results. Finally, we will discuss our findings, draw conclusions and implications, and then highlight the limitations of our study.

\section{Theoretical Background}

The startup capital needed for starting a business may come from the founding team of the new venture, family members or friends, but the increasing amount of capital needed to survive often outweighs the sustainability of the group [11]. However, due to the severe information asymmetry between new enterprises and potential investors, only a few of those enterprises can attract supports from external funds. In such situations, in order to reduce uncertainty, investors' reliance on signals is key for improving their assessment of the future value and quality of the new venture [6]. Many scholars have used signaling theory, according to entrepreneurship literature, when assessing the viability of ventures by looking for signals; since quality is a potential capability of the signal sender, it can satisfy the needs and requirements of the external observer of the target object. In this manner, one can assess the underlying quality of entrepreneurial ventures [12].

Signaling theory claims that in order to resolve information asymmetries entrepreneurs transmit costly signals $[7,13]$. Although a signal may be important to the sender, it is an underlying feature that is relevant to the decision maker and is therefore more valuable 
because of its high cost. Management and entrepreneurship scholars have found that there are some distinct signals that help diminish uncertainty about ventures' quality, and for the key stakeholder these signals can consist of relationships with status actors, future prospects [6], founding members' individual qualities, top management team composition [14], board characteristics [15], and patents [16]. In much of the existing research, the focus has been on startups and mature industries in the later stages of their life cycle [17]; however, there has been very little research on the early stages of new ventures.

\subsection{Signal Effects with CEO Characteristics}

If there is a lack of performance track records in the earliest stages of development of a new venture, the venture's viability is signaled by the venture's founding members [18]. The composition of the management team or founding members' individual qualities are examples of such signals. For investors, the entrepreneur's human capital is an important indicator of whether a new venture will succeed in the future [19]. Thus, signaling theory and human capital theory are directly linked due to the fact that signaling theory mirrors the signal receivers' faith of the connection between performance and human capital [20].

An outstanding role in investment decisions is played by the venture's CEO's human capital. The human capital tendencies of top executives send off a particularly strong signal considering the direction of the future development of the organization, which is affected by their strategic decisions. Many previous studies have found that organizational outcomes are influenced by the CEO's human capital in terms of experience [20,21]. With regards to the performance of those new ventures and small businesses, CEOs' heavy involvement in daily operations is highly influential [22]. What becomes apparent is that in order to find more funding from VCs, the CEO's experience is crucial as it signals her or his capability to successfully manage the venture.

\subsection{Third-Party Signaling}

Signaling theory is interested in reducing the imbalance of information by regarding one party while they examine the quality of another [23]. Especially for new ventures nearing IPO, there are also scholars who pay particular attention to their third party signals because they could indicate an increase in market valuations [6]. The function of the third party signal to the listed company is as important as the confirmation of enterprise value. If potential investors do not think they have more information, they will try to reduce the information asymmetry between the new venture and themselves in other ways [24], such as a certifying institution [25], a discerning intermediary [26], or any authoritative third-party guarantee [13].

A company needs to submit some materials in the process of carrying out an IPO, which should include its financial situation, management team, corporate governance structure, and business model. However, it is not enough to make investment decisions through these materials. Based on this, the certification of third-party institutions has become particularly important as a signal to the companies that are carrying out IPOs. Compared with companies at the IPO stage, new ventures may provide less information to potential investors, since they selectively provide information to potential investors, who have no access to the new ventures' fund usage or record of achievements. Therefore, the information provided by new ventures is incomplete and vague for investors. In this case, the role of the signal of the third party will be very obvious. However, Internet financial enterprises like P2P lending, as e-financial service intermediaries, are different from technology enterprises in that we cannot judge the quality of new enterprises in their early stages through third-party signals such as patents or government subsidies [10].

$\mathrm{P} 2 \mathrm{P}$ lending is an emerging industry with rapid growth in China. However, due to the imperfect legal system in China, although new companies are established every month, there are still many enterprises going out of business every month. Therefore, we should focus on whether third-party signals reflect the viability of new enterprises. 


\section{Hypotheses Development}

\subsection{Founder-CEO of New Ventures}

In terms of the founder identity of the CEOs, it usually represents indicates that they may have some special ability and knowledge, which gives them enough confidence to face difficulties and make strategic decisions when they decide to start a business. For example, founder-CEOs usually have a technical background and may have a more detailed understanding of the technology in the industry. Additionally, this technology is the basis for developing products suitable for the market. Founders are often university and public institute scientists who originally cultivated the venture's technology in high technology industries. Second, the ventures' founder-CEOs have likely acquired a large amount of employees from the venture. The founder-CEO crafts a vision for employees, and incentivizes employees to work hard and develop products to achieve this vision using his or her own charm [22]. That is, due to the fact that the CEOs have worked with these employees since the beginning of the enterprise, founder-CEOs have founder-based and firm-specific knowledge about the motivations and competencies of their employees. This knowledge allows them to use their employees more efficiently by benefiting from their individual competencies. CEOs that lack experience working alongside their employees, i.e., firm-specific founder-based experience, may allocate employees in ways that do not utilize their abilities and competencies accurately. This could be damaging to the organization as the employees are distributed across projects in a suboptimal way:

Hypothesis 1 (H1). The founder-CEOs of new ventures have a higher likelihood of venture capital funding in the ventures' early stage of development.

\subsection{Human Capital of CEO in New Ventures}

Industry experience: The industry-specific experience that the CEOs have accumulated is important because it gives information on the threats, opportunities, and regulations specific to the industry, as well as competitive conditions [27]. This knowledge is utilized in a way that allows industry-experienced managers to effectively judge information gathered about customers and potential competitors, which consequently improves the identification and judgment of possible new opportunities and resulting decision making [28]. In China, P2P lending is an important part of Internet finance. Because of the widespread bankruptcy of small and medium-sized new ventures after 2008, banks are more cautious when dealing with the loan applications of SMEs or individuals, which increases the difficulty they encounter when applying for loans.

First, as an emerging financing channel, P2P lending provides a new approach for loans to SMEs or individuals. Unlike technology companies, which need various kinds of technology to improve their competitiveness, the essence of P2P lending is service rather than creation. Hence, we value the experience of the financial industry more. Second, as an Internet finance new venture, it cannot be separated from information technology. In the past decade, the P2P lending industry has achieved rapid development through the Internet. Every P2P lending firm has its own website and online transaction process. Therefore, due to the nature of the P2P lending industry, whether the CEO has industry experience in finance and in information technology (IT) is what we should focus on.

Practical research has proven that when industry-experienced managers lead ventures they experience higher growth rates in comparison to ventures that are led by managers lacking this experience [27,29], which supports the idea that industry-specific experience is an important part of a CEO's human capital. Therefore, it is easier to obtain investment when the $\mathrm{CEO}$ has experience in the financial industry and the internet industry. 
Hypothesis 2-1 (H2-1). When the new enterprise's CEO has experience with the financial industry, it is more likely to obtain financing.

Hypothesis 2-2 (H2-2). When the new enterprise's CEO has experience with the IT industry, it is more likely to obtain financing.

International experience: Experience gained through education or working overseas can serve as international experience [30]. Some researchers who have previously focused on strategic management have suggested that the international experience of companies top management has a positive impact on business performance. These studies further demonstrated that CEOs' international experience is beneficial to business development. In other words, CEOs' international experience assists in developing skills, global networks, distinctive worldviews and the ability to process dynamic and complex information. Such capabilities and skills can be valuable resources for competitive advantage and superior corporate performance because they are perceived to be scarce and valuable [31].

Executives have unique international experience that cannot be gained by working in their home countries. Although adults may be limited by what they learn in their environment growing up, this is not the case when it comes to living and working in foreign environments which may prove to be more educational [32]. Every country is different, and these differences may not only be reflected in culture, but also in economic development and institutional environment. While these differences can cause culture shock and many difficulties and problems for executives living and working overseas, they also stimulate their desire to learn and gain more valuable experience. Therefore, a $\mathrm{CEO}$ with international experience can learn more in adversity and thus cultivate stronger abilities [33], which could hardly be surpassed by one with no international experience.

Hypothesis 2-3 (H2-3). The greater their CEOs' international experience, the more likely are new ventures to obtain venture capital funding in their early stage of development.

\subsection{Legitimacy of New Ventures}

\subsubsection{Internet Content Provider (ICP) License}

Although Internet technology and entrepreneurial activities have flourished in recent years, many Internet companies still fail. Similar to signaling theory, Reuber and Fischer [34] described how the lack of a track record in a young venture causes outsiders to become skeptical of the possibility of its future success. This is because young ventures commonly operate with immature and unrefined activities and have little production experience. Furthermore, new ventures lack business history and have less information to show to capital providers, making it difficult for them to judge new ventures' potential future performance. For Internet companies, Internet content providers can reflect the viability of new ventures.

Different rules and laws are enforced on Chinese ICPs than on other non-financial internet companies due to the fact that they are under the classification of media organizations, which leads to heavy regulation in China. Firstly, the Department of Propaganda of the Central Committee of the Communist Party of China directly supervises ICPs, while the State Council's Information Department supervises all of the work of the Department of Propaganda. As far as China's institutional environment is concerned, ICPs are recognized by the government and have certain authority. In comparison to other countries, censorship in China involves different levels of technological control and legal regulation, and is exponentially advanced, pervasive and effective. China utilizes a 30-thousand member cyber police force dedicated to monitoring online activities [35].

To apply for founding an ICP, one must meet the following requirements: (1) There are funds and professionals available for development and operation. (2) There are business development plans and related technology solutions. (3) The operator has the credit or capacity to provide long-term service to users. (4) The operator is a company established ac- 
cording to law, and its registered capital shall be 1 million or more. (5) Documents that have obtained the consent of the relevant competent departments concerning the information service that require pre-approval as stipulated in the ICP management measures. (6) Sound network and information security measures, including website security measures, user information and a system of information security management. (7) Other requirements stipulated by the state. Two central aspects of an effective signal are espoused by this signaling mechanism: costliness and observability.

Hypothesis 3-1 (H3-1). When new ventures are certified as legal, they are more likely to obtain venture capital funding in their early stage of development.

\subsubsection{Industry Associations}

Delmar and Shane [36] implied that legitimacy is also important, as the biggest issue new ventures often face is survival rather than their current financial performance. Ways of acquiring legitimacy would be for a new venture to adopt industry technology, practices, norms, and standards; or in short, industry members' past actions [37]. Hence, in addition to technology and finance, a new venture can develop legitimacy by actively participating in trade associations to demonstrate their viability. Lindberg, et al. [38] proposed that trade associations have the functions of stabilizing the market environment and maintaining market order; and Hollingsworth, et al. [39] proposed that trade associations not only include the above two functions but also regulate the inter-industry competition and protect the interests of enterprises in the industry. In order to build their own positive brand benefits, the members of the trade association will exclude bad enterprises from the association, so the internal members of the trade association will also prevent bad enterprises from entering the association. Therefore, differently from external regulations such as ICP, industry associations are a regulatory force within the industry. They will actively develop and maintain a good industry environment conductive to the long-term survival of enterprises.

Hypothesis 3-2 (H3-2). When new ventures join industry associations, they are more likely to obtain venture capital funding in their early stage of development.

\section{Methodology}

\subsection{Sample and Data}

The research of this paper mainly focuses on the acquisition of resources and signaling of new ventures. We collected all Chinese P2P lending companies as of March 17, 2019, with a total of 6555 companies, including those that have been closed. The data comes from WDZJ (www.wdzj.com), a third-party information website for the Chinese online lending industry. In the end, only 2388 companies provided their CEOs' information. Similar to [40] the approach of, new ventures would be, by our definition, independent new ventures that have existed for 10 years or less. We found that 2388 companies were within 10 years of age. Among them, 1377 (57.66\%) firms were less than 3 years old, 1006 (42.13\%) firms had existed 3-7 years, and $4(0.21 \%)$ firms had existed for more than 8 years. The 10 -year range was decided upon because it more accurately represents the growth from a new venture to an adolescent venture. We focused on one industry, the P2P lending industry, for multiple reasons. First, to reduce alternative explanations for desirable funding amounts and human capital requirements, it was better to focus on a single industry. Second, with the development of the Internet, the P2P lending industry has received widespread attention and even threatened the status of the bank. Third, the information of companies' managers as an investment signal is insufficient because the information in the industry is characterized by uncertainty. Therefore, companies need to have different levels of human capital and other activities to reduce concerns of biased selection.

Our data are mainly from WDZJ (www.wdzj.com) and Zero2IPO. The WDZJ database provides information about P2P lending companies [41,42]. Since the WDZJ database is the 
first P2P online lending industry website in China, it provides full-scale and authoritative statistics regarding P2P lending companies. The WDZJ database has been widely used in previous research of $\mathrm{P} 2 \mathrm{P}$ lending. In this study it is an important source of data. This source is deemed accurate due to the fact that registered business owners have each entered the information and it has been periodically updated. To show users the high quality of their products, companies have a strong incentive to disclose related information in order to distinguish them from other companies. We used Zero2IPO to improve the part of corporate financing information. A leading web portal in private equity industry and venture capital in China is called PEdaily.cn. The PEdaily.cn focus on sharing timely news and in-depth analyses with its users, and provides abundant data when integrated with the strongest research resources and networks of the Zero2IPO Group. Thus Zero2IPO has a nearly exhaustive list of VC investments in China.

\subsection{Measures}

\subsubsection{Dependent Variables}

Venture capital financing. We sorted P2P lending companies that have been involved in venture capital financing found on the two databases WDZJ and Zero2IPO and marked them as 1 , and 0 otherwise, which is a binary indicator variable that helps identify whether a startup received external funding from one of the venture capital firms or not.

\subsubsection{Independent Variables}

We collected all of the P2P lending companies' CEOs' introductions in the WDZJ database. Each company will disclose the relevant information to the greatest extent to distinguish them from other companies. To verify the first hypothesis, we extracted keywords from the CEO profiles, with the founder, co-founder, and founding team members as 1 , otherwise 0 . For CEOs' human capital, we weighed CEOs' industry experience according to their related financial work experience. We weighed international experience according to overseas study experience or overseas work experience. We judged the company's legitimacy through the license of Internet content providers (ICP) and whether companies were members of industry associations. Enterprises that held a license as Internet content providers (ICP) were given a value of 1 , and 0 otherwise. Likewise, if the company was a member of an industry association before obtaining financing, then it was measured as 1 , and 0 otherwise. At the same time, we also consider that there may be a mutual causal relationship between the third party signals and VC Funding, so we confirm the data. We checked three dates: the time of new venture joining the association, the time of obtaining ICP certification and the time of obtaining VC funding. The data shows that the time when new venture has third-party authentication is before the VC funding time, so there is no possibility of mutual cause and effect between the two variables.

\subsubsection{Control Variables}

Our study controlled for a number of factors that may influence venture capital. First, the geographic location was controlled, which accounts for the spatial proximity to the investors [43]. Geographic location was coded for ventures that were in the investments' top 10 cities (i.e., Beijing, Shenzhen, Shanghai, Guangzhou, Hangzhou, Suzhou, Wuhan, Changsha, Nanjing, and Ningbo) and 0 was chosen for ventures in other areas [44]. Next, we controlled the natural logarithm of firm age because there may be a preference by investors for ventures that are more established and have market positions that are also established [45]. Firm age is measured as years from the date of registration. Third, a firm's size and age can be considered as signals of viability, as they may represent an organization's ability to undertake new responsibilities [46]. It should be noted that the $\log$ of the registration capital is what is considered as firm size. Fourth, there is practical research that shows that $\mathrm{P} 2 \mathrm{P}$ lending firms with state-owned affiliations commonly attract more investors and enjoy larger transaction volumes. P2P lending firms with state-owned affiliations are substantially less likely to default [2]. If the enterprise was state-owned 
it was marked as 1 , and 0 otherwise. Fifth, if a parent company is a company that is listed or a company invested in by a listed company, we regarded it as a company with a listing background. A company with such a background has already been reviewed for its corporate quality, so we measured a company with a listing background as 1 , and 0otherwise. Sixth, Marlow and Patton [47] noted that compared with men, female entrepreneurs may be at a disadvantage in social competition. Some past studies have shown that even though similar attempts were made to gain an array of external funding, it has proven much more difficult for women to gain funding in comparison to their male counterparts [48]. Thus, we also controlled for gender, encoding male CEOs as 1 and others as 0 . Since we used a binary variable to measure the dependent variables, we conducted a logistic regression analysis of the data through STATA 14.0.

\section{Analyses and Results}

As shown in Table 1, descriptive statistical analysis and Pearson correlation analysis were conducted. We transformed firm size into their natural logarithms, a commonly used technique, to make the residuals more symmetrically distributed to form a bell shape, because natural log transformation can squeeze the large values of the variables together and spread the small values out. In other words, log transformation increases the normality of the errors, which ensures that the model inference is valid. We present the means, standard deviations, and correlations among variables in Table 1. In our research sample, $7 \%$ of new ventures obtained VC financing and the ratio of male Founder-CEOs is $54 \%$. As can be seen from descriptive statistics, $83 \%$ of CEOs have financial industry experience, while only $8 \%$ have IT industry experience and overseas experience. This phenomenon also prompts us to explore whether IT industry experience will impact obtaining VC financing. We also found that out of the 2388 new ventures, only $9 \%$ of new ventures have joined industry associations, and $16 \%$ of new ventures have obtained ICP certification. The variable selected in this study has a small dispersion coefficient from the comparison of standard deviations and mean values of each variable. The results show that our sample distribution is roughly regionally balanced, so it helps reduce errors in the test process and get more realistic conclusions. All independent variables were positively related to corporate diversification. Across all covariates, the correlations were commonly low. Additionally, using variance inflation factors (VIFs), we examined multicollinearity. Pragmatically, we considered serious signs of multicollinearity to be VIFs exceeding 10. However, given that the VIFs for all variables were $<2$, it can be deduced that multicollinearity is not a substantial concern.

We conducted logistic regression analysis to measure the impact of CEO characteristics and corporate legitimacy signals on venture capital financing, and all of the models were statistically significant. Table 2 shows the logistic regression analysis results. First, logistic regression analysis was performed for all of the control variables, referring to model 1 in Table 2. This comes as a surprise, given the impact of geographic location on the gain venture capital financing of P2P lending companies as Internet ventures. Even though Internet companies can do business all over the country, the results show that if a new venture's location is was in the top 10 cities (i.e., Beijing, Shenzhen, Shanghai, Guangzhou, Hangzhou, Suzhou, Wuhan, Changsha, and Ningbo), then it is was easier for them to obtain VC funding. Moreover, the longer an enterprise operated, the easier it was to get VC funding. Other control variables had no significant effect in our model. 
Table 1. Descriptive statistics and correlation analysis.

\begin{tabular}{|c|c|c|c|c|c|c|c|c|c|c|c|c|c|c|c|}
\hline & Mean & Std. Deviation & 1 & 2 & 3 & 4 & 5 & 6 & 7 & 8 & 9 & 10 & 11 & 12 & 13 \\
\hline 1. VC financing & 0.07 & 0.252 & 1.000 & & & & & & & & & & & & \\
\hline 2. Geographic Location & 0.61 & 0.487 & 0.133 ** & 1.000 & & & & & & & & & & & \\
\hline 3. Firm Age & 2.62 & 1.575 & $0.281 * *$ & 0.111 ** & 1.000 & & & & & & & & & & \\
\hline 4. State Owned & 0.08 & 0.267 & -0.004 & 0.040 & $0.099 * *$ & 1.000 & & & & & & & & & \\
\hline 5. Listed background & 0.03 & 0.176 & $0.093^{* * *}$ & $0.090^{\text {** }}$ & $0.185^{* *}$ & -0.053 * & 1.000 & & & & & & & & \\
\hline 6. Firm Size $(\ln )$ & 2.85 & 0.059 & 0.071 ** & $0.202 * *$ & $0.134 * *$ & $0.107^{* *}$ & $0.094 * *$ & 1.000 & & & & & & & \\
\hline 7. CEO_gender & 0.89 & 0.309 & 0.013 & $0.066^{* *}$ & -0.038 & -0.006 & -0.022 & -0.004 & 1.000 & & & & & & \\
\hline 8. CEO_founder & 0.54 & 0.498 & $0.059^{* *}$ & 0.000 & -0.003 & -0.010 & -0.025 & $-0.046^{*}$ & 0.030 & 1.000 & & & & & \\
\hline $\begin{array}{l}\text { 9. Financial_- } \\
\text { industy experience }\end{array}$ & 0.83 & 0.374 & $0.041 *$ & $0.058^{* *}$ & $0.079 * *$ & $0.050 *$ & 0.011 & $0.065^{* *}$ & 0.008 & -0.010 & 1.000 & & & & \\
\hline 10. IT_industy_experience & 0.08 & 0.273 & $0.053 * *$ & $0.056^{* *}$ & $0.049 *$ & -0.017 & -0.002 & 0.014 & $0.058^{* *}$ & -0.025 & -0.006 & 1.000 & & & \\
\hline 11. International_experience & 0.08 & 0.278 & $0.086^{* *}$ & $0.092 * *$ & $0.050 *$ & 0.008 & 0.031 & 0.037 & -0.027 & -0.009 & $0.043 *$ & 0.153 ** & 1.000 & & \\
\hline 12. Industry Association & 0.09 & 0.292 & $0.208^{* *}$ & $0.138^{* *}$ & $0.268^{* *}$ & $0.089^{* *}$ & $0.162 * *$ & $0.121 * *$ & -0.028 & 0.032 & $0.059 * *$ & $0.041 *$ & $0.063^{* *}$ & 1.000 & \\
\hline 13. ICP Certification & 0.16 & 0.368 & $0.161^{* *}$ & $0.144^{* *}$ & $0.338^{* *}$ & $0.090 * *$ & $0.096^{* *}$ & $0.173^{* *}$ & -0.014 & 0.015 & 0.008 & 0.007 & 0.039 & $\underset{* *}{0.163}$ & 1.000 \\
\hline
\end{tabular}

Note: ${ }^{*} p<0.05 ; * * p<0.01$ 
Table 2. Different signaling effects on venture capital financing.

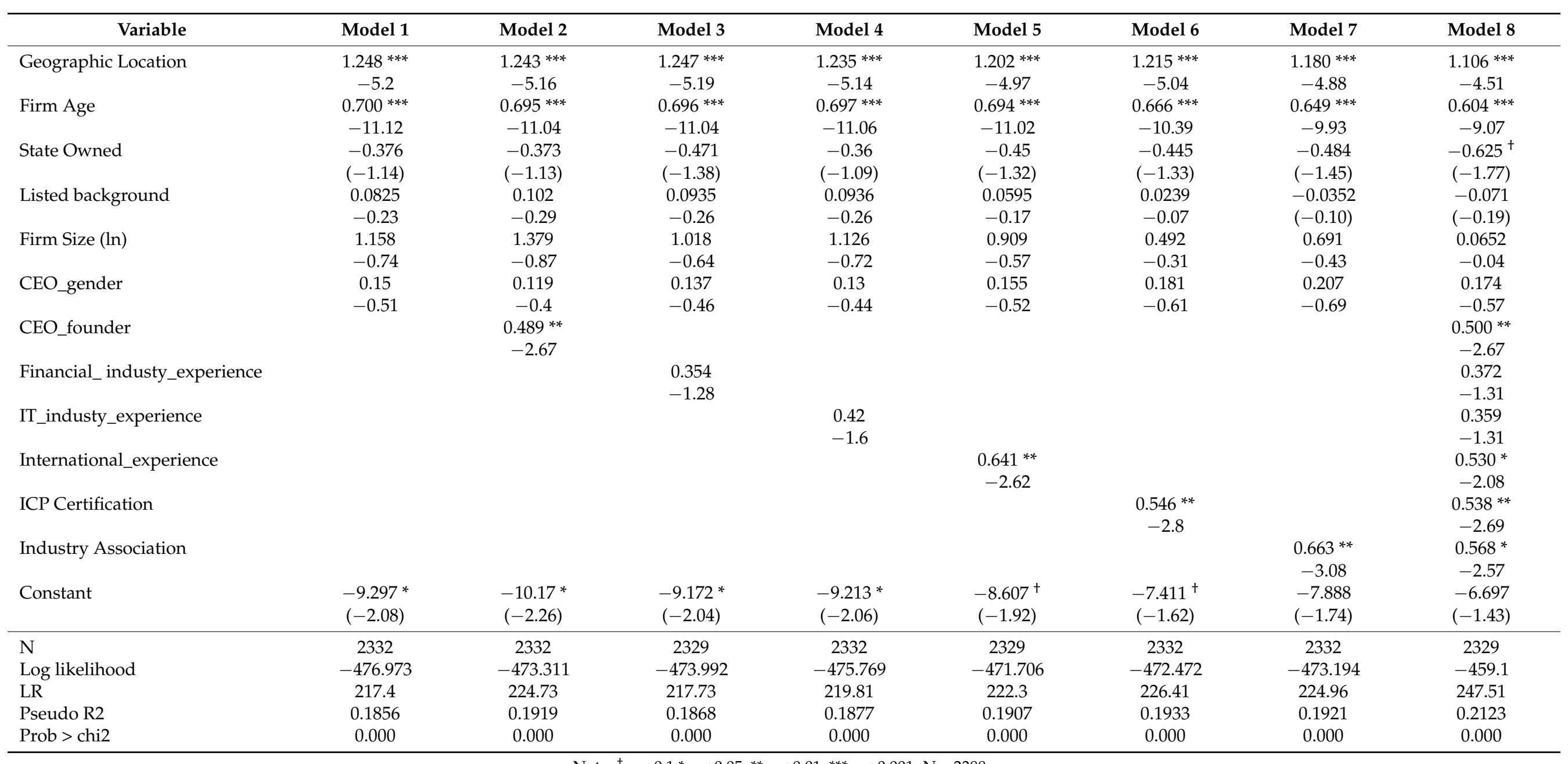


We conducted a regression analysis of each independent variable in turn to obtain Models 2-7. Model 2 allowed us to test Hypothesis 1, which argued that the CEO is a founder who has a significant signaling influence on venture capital financing. A CEO that is a founder was found to have a positive impact on the ability to obtain venture capital in a statistically significant manner $(p<0.01, \beta=0.489)$. Thus, Hypotheses 1 was supported. In other words, when the CEO is the founder, the new venture is more likely to obtain venture capital financing.

Model 3 to Model 5 show international experience and industry experience as human capital in relation to venture capital financing (i.e., Hypotheses 2-1, 2-2, and 2-3). The results of our analysis suggest that the hypothesis we have set up is only partially supported, in that only the international experience of CEOs was significant $(p<0.01, \beta=0.641)$. Thus, hypothesis 2-2 was supported, hypothesis 2-1 and 2-3 was not supported. In other words, the CEO's international experience is important for venture capital financing, whereas financial industry experience and IT industry experience are not important. Model 6 and Model 7 report the direct influence of the legitimacy of the new venture (i.e., the license of Internet content providers (ICP) and trade associations) on venture capital financing. Consistent with Hypotheses 3-1 and 3-2, the license of Internet content providers (ICP) $(p<0.01, \beta=0.546)$ and industy associations $(p<0.01, \beta=0.663)$ were both positive. Thus, Hypotheses 3-1 and 3-2 were both supported. A full model is provided in Model 8. The outcomes in Models 2-7 and 8 are consistent.

In our research model, third-party signals may be endogenous variables, so we conducted the Hausman test for two independent variables (Association and ICP) of the third party signal. To control for potential selection bias, scholars all use the instrumental variable method for the endogeneity test, and the premise of the instrumental variable method is the existence of endogenous variables. Therefore, we must carry out the Hausman test, whose original assumption is that "all main variables are exogenous variables". If $p>0.05$, there is no endogenous variable. We used the GDP of each province as the instrumental variable. Because the association is the industry association of each province, they have relevance. In general, the region that is fast economic development has strong administrative executive ability. In other words, provinces with faster economic growth are more likely to gain ICP for New Venture. The Hausman test results show that neither variable is endogenous. Since traditional Hausman tests did not hold in the context of insisting on heteroscedasticity, we did a DWH test, and the result showed no endogenous variable.

\section{Discussion and Conclusions}

Our work provides evidence that CEO is founder, CEOs' human capital and thirdparty signals of new ventures are key signals for P2P lending companies. We found that, compared with high-tech startups, non-tech start-ups can not only demonstrate the quality of the company by their CEO's characteristics, but also reflect the high quality of the company to investors through third party.

Our findings make contribution in several ways. We theorize about the characteristics of CEO and the influence of third party signals on VC financing. First, our study confirms the positive influence of CEOs' founder status and international experience on VC financing. Many studies focus on management education of the CEO [5] and prior professional experience [45]. However, our study highlights that the founder status of CEO builds VC's confidence in the new venture. For new ventures of the emerging industry, they lack history, so they have high uncertainty. Investors need to gauge a new venture's prospects based on the characteristics of the CEO. The founder's status represents his sense of identity and enthusiasm for the new venture, and the founder will manage his own business cautiously. However, some new ventures will avoid being the founder and CEO at the same time to avoid legal liability if they set up the new venture for cheating. We emphasize that emerging industry like P2P Lending is the result of the combination of finance and the Internet. Although the industry experience is important for the development of an enterprise and the acquisition of VC financing [15], and previous studies have shown 
that for new ventures, the industry experience of the CEO can indicate that the team has enough social capital to achieve high performance [5]. However, our study found that the industry experience does not influence VC financing. As the P2P lending industry is nascent and inter-sectoral service, professional industry experience and knowledge in traditional sectors may be less significant, such as financial background required by the traditional finance industry or computer background required by the IT industry. As an online financial intermediary, the CEO's industry experience may have little impact on its development, as it only needs to deal with the transaction process of debit and credit. Besides, it is important that the international experience represent the ability of the CEO. The international experience of CEO signals their ability to develop and guide industry changes. The international experience of CEO signals their ability to develop and guide industry changes.

Second, investors should not ignore third party signals. For fintech, it is not enough for investors to focus only on the characteristics of CEOs. Because of the high asymmetry of information in this industry, we propose that investors pay attention to the third party's signals. Third, many previous studies have explored the meaning of third-party signals, their sources focus on the approval of high-quality large companies, public agency research grants [10], and a reputable third-party, such as a venture development organizations(VDO) [13]. However, we have discovered new signal sources. The difference between industry association and ICP is that the former is a self-organized group institution among enterprises in the industry, whose purpose is to cooperate each other among enterprises and to represent members' stakes and voices to governments and other institutions; ICP is a certification recognized by the government. In China, where the Internet is developing rapidly, the government needs to properly supervise the market's development to avoid the undesirable development of emerging industries like fintech. Therefore, ICP has legitimacy and convey that new venture is of "high quality" to investors. Third party signals can show the quality of new ventures to potential investors in the process of new ventures searching for external investment.

From a practical perspective, for the new ventures at the early stage seeking potential investors for survival should actively increase their third-party recognition, such as by seeking government certification or obtaining industry recognition. For new ventures, external and internal industry recognition speaks to their quality. Thus for the new ventures at the early stage seeking potential investors for survival should actively increase their third-party recognition, such as by seeking government certification or obtaining industry recognition. For new ventures, external and internal industry recognition speaks to their quality of services and new ventures. Thus, it is necessary to make new ventures aware of the value of third party signals, so as to help new ventures find potential investors. However, the role of third party signals in the process of seeking external investment has been largely ignored, though many previous studies have verified that the characteristics of entrepreneurs and CEOs play an important role in new ventures' attempts to obtain venture capital financing, especially for new ventures at their early stage [19]. This results can be applied to other new ventures of emerging industries when startups need to VC investment.

Despite our findings, our research is subject to some limitations, which may undeniably provide research opportunities for future research. First, because of data limitations, we cannot identify any other positions except founder-CEO, equity ownership, and other characteristics of CEO or founders. Second, we have no information on more detailed information on VC investment such as total amount of investment and total round of investment. This information on VC investment can help to understand the relationships of CEO experience and third-party signals with VC investment. Third, we only identified some third-party signals for new ventures. Future studies can extend more institutions or mechanisms of third-party signals for early stage of new ventures.

Also future research can analyze the relationship between the legitimacy of resource acquisition and founders' information and social capital, such as CEOs' startup experience. We hypothesized about the industry experience in the context of finance. Because of the 
limitations of the data, we could only find information about CEOs' financial experience. However, whether the $\mathrm{CEO}$ has $\mathrm{P} 2 \mathrm{P}$ lending industry experience and managerial experience are very important. We, unfortunately, were not able to differentiate these data ourselves, but expect they may be of importance to future investors. Furthermore, scholars can collect relevant data from other databases for analysis. In our study, we used numerous dummy variables. Nevertheless, future research may use continuous variables to add to these ideas in order to explore the change in these relationships with in regards to signal strength. We focused on a specific type of venture in a specific industry, which belongs to the financial industry. We are not sure whether it is applicable to non-financial industries. Furthermore, we only focused on growth-oriented ventures, which are more likely to seek external investment for survival in contrast to other types of companies.

Author Contributions: Conceptualization, H.Z. and S.P.; Data curation, H.Z. and X.P.; Formal analysis, H.Z.; Methodology, S.P.; Writing—original draft, H.Z.; Writing—review \& editing, S.P. All authors have read and agreed to the published version of the manuscript.

Funding: This research received no external funding.

Institutional Review Board Statement: Not applicable.

Informed Consent Statement: Not applicable.

Data Availability Statement: In our study, all the data was mainly from "WDZJ (www.wdzj.com)" and Zero2IPO. Due to data privacy issues and database permissions, our data should not be shared in this study.

Conflicts of Interest: All authors declare no conflict of interest.

\section{References}

1. Amit, R.; Glosten, L.; Muller, E. Entrepreneurial ability, venture investments, and risk sharing. Manag. Sci. 1990, 36, 1233-1246. [CrossRef]

2. Jiang, J.; Liao, L.; Wang, Z.; Zhang, X. Government Affiliation and Fintech Industry: The Peer-to-Peer Lending Platforms in China. Available online: https: / / ssrn.com/abstract=3116516 (accessed on 1 January 2021).

3. Ziegler, T.; Shneor, R.; Wenzlaff, K.; Wang, B.W.; Kim, J.; Odorovic, A.; de Camargo Paes, F.F.; Suresh, K.; Zhang, B.Z.; Johanson, D.; et al. The Global Alternative Finance Market Benchmarking Reporttrends, Opportunities and Challenges for Lending, Equity, and Non-investment Alternative Finance Models; Cambridge Centre for Alternative Finance: Cambridge, UK, 2020.

4. Courtney, C.; Dutta, S.; Li, Y. Resolving information asymmetry: Signaling, endorsement, and crowdfunding success. Entrep. Theory Pract. 2017, 41, 265-290. [CrossRef]

5. Patzelt, H. CEO human capital, top management teams, and the acquisition of venture capital in new technology ventures: An empirical analysis. J. Eng. Technol. Manag. 2010, 27, 131-147. [CrossRef]

6. Higgins, M.C.; Gulati, R. Stacking the deck: The effects of top management backgrounds on investor decisions. Strateg. Manag. J. 2006, 27, 1-25. [CrossRef]

7. Spence, M. Job market signaling, Uncertainty in Economics. Q. J. Econ. 1978, 87, 355-374. [CrossRef]

8. Becker, G.S. Investment in human capital: A theoretical analysis. J. Political Econ. 1962, 70, 9-49. [CrossRef]

9. Tzabbar, D.; Margolis, J. Beyond the startup stage: The founding team's human capital, new venture's stage of life, founder-CEO duality, and breakthrough innovation. Organ. Sci. 2017, 28, 857-872. [CrossRef]

10. Islam, M.; Fremeth, A.; Marcus, A. Signaling by early stage startups: US government research grants and venture capital funding. J. Bus. Ventur. 2018, 33, 35-51. [CrossRef]

11. Cassar, G. The financing of business start-ups. J. Bus. Ventur. 2004, 19, 261-283. [CrossRef]

12. Jain, B.A.; Jayaraman, N.; Kini, O. The path-to-profitability of Internet IPO firms. J. Bus. Ventur. 2008, 23, 165-194. [CrossRef]

13. Plummer, L.A.; Allison, T.H.; Connelly, B.L. Better together? Signaling interactions in new venture pursuit of initial external capital. Acad. Manag. J. 2016, 59, 1585-1604. [CrossRef]

14. Lester, R.H.; Certo, S.T.; Dalton, C.M.; Dalton, D.R.; Cannella Jr, A.A. Initial public offering investor valuations: An examination of top management team prestige and environmental uncertainty. J. Small Bus. Manag. 2006, 44, 1-26. [CrossRef]

15. Certo, S.T. Influencing initial public offering investors with prestige: Signaling with board structures. Acad. Manag. Rev. 2003, 28, 432-446. [CrossRef]

16. Hoenig, D.; Henkel, J. Quality signals? The role of patents, alliances, and team experience in venture capital financing. Res. Policy 2015, 44, 1049-1064. [CrossRef]

17. Arthurs, J.D.; Busenitz, L.W.; Hoskisson, R.E.; Johnson, R.A. Signaling and initial public offerings: The use and impact of the lockup period. J. Bus. Ventur. 2009, 24, 360-372. [CrossRef] 
18. Spence, A.M. Market Signaling: Informational Transfer in Hiring and Related Screening Processes; Harvard University Press: Cambridge, MA, USA, 1974; Volume 143.

19. Baum, J.A.C.; Silverman, B.S. Picking winners or building them? Alliance, intellectual, and human capital as selection criteria in venture financing and performance of biotechnology startups. J. Bus. Ventur. 2004, 19, 411-436. [CrossRef]

20. Ko, E.-J.; McKelvie, A. Signaling for more money: The roles of founders' human capital and investor prominence in resource acquisition across different stages of firm development. J. Bus. Ventur. 2018, 33, 438-454. [CrossRef]

21. Berger, A.N.; Udell, G.F. The economics of small business finance: The roles of private equity and debt markets in the financial growth cycle. J. Bank. Financ. 1998, 22, 613-673. [CrossRef]

22. Wasserman, N. Founder-CEO succession and the paradox of entrepreneurial success. Organ. Sci. 2003, 14, 149-172. [CrossRef]

23. Spence, M. Signaling in retrospect and the informational structure of markets. Am. Econ. Rev. 2002, 92, 434-459. [CrossRef]

24. Haunschild, P.R. How much is that company worth?: Interorganizational relationships, uncertainty, and acquisition premiums. Adm. Sci. Q. 1994, 39, 391-411. [CrossRef]

25. Baum, J.A.C.; Oliver, C. Institutional linkages and organizational mortality. Adm. Sci. Q. 1991, 36, 187-218. [CrossRef]

26. Rao, H. The social construction of reputation: Certification contests, legitimation, and the survival of organizations in the American automobile industry: 1895-1912. Strateg. Manag. J. 1994, 15, 29-44. [CrossRef]

27. Kor, Y.Y. Experience-based top management team competence and sustained growth. Organ. Sci. 2003, 14, 707-719. [CrossRef]

28. Castanias, R.P.; Helfat, C.E. The managerial rents model: Theory and empirical analysis. J. Manag. 2001, 27, 661-678. [CrossRef]

29. Eisenhardt, K.M.; Schoonhoven, C.B. Organizational growth: Linking founding team, strategy, environment, and growth among US semiconductor ventures, 1978-1988. Adm. Sci. Q. 1990, 35, 504-529. [CrossRef]

30. Sambharya, R.B. Foreign experience of top management teams and international diversification strategies of US multinational corporations. Strateg. Manag. J. 1996, 17, 739-746. [CrossRef]

31. Daily, C.M.; Certo, S.T.; Dalton, D.R. International experience in the executive suite: The path to prosperity? Strateg. Manag. J. 2000, 21, 515-523. [CrossRef]

32. Leung, A.K.-y.; Maddux, W.W.; Galinsky, A.D.; Chiu, C.-Y. Multicultural experience enhances creativity: The when and how. Am. Psychol. 2008, 63, 169. [CrossRef]

33. Le, S.; Kroll, M. CEO international experience: Effects on strategic change and firm performance. J. Int. Bus. Stud. 2017, 48, 573-595. [CrossRef]

34. Reuber, A.R.; Fischer, E. The company you keep: How young firms in different competitive contexts signal reputation through their customers. Entrep. Theory Pract. 2005, 29, 57-78. [CrossRef]

35. Batjargal, B. Internet entrepreneurship: Social capital, human capital, and performance of Internet ventures in China. Res. Policy 2007, 36, 605-618. [CrossRef]

36. Delmar, F.; Shane, S. Legitimating first: Organizing activities and the survival of new ventures. J. Bus. Ventur. 2004, 19, 385-410. [CrossRef]

37. Deeds, D.L.; Mang, P.Y.; Frandsen, M. The quest for legitimacy: A study of biotechnology IPO's. Front. Entrep. Res. 1997, 1, 533-543.

38. Lindberg, L.N.; Campbell, J.L.; Hollingsworth, J.R. Economic governance and the analysis of structural change in the American economy. Gov. Am. Econ. 1991, 5, 3.

39. Hollingsworth, J.R.; Schmitter, P.C.; Streeck, W. Capitalism, Sectors, Institutions, and Performance; Oxford University Press: Oxford, UK, 1994.

40. Shepherd, D.A. Venture capitalists' introspection: A comparison of "in use" and "espoused" decision policies. J. Small Bus. Manag. $1999,37,76$.

41. Gong, Q.; Liu, C.; Peng, Q.; Wang, L. Will CEOs with banking experience lower default risks? Evidence from P2P lending platforms in China. Financ. Res. Lett. 2020, 36, 101461. [CrossRef]

42. Gao, M.; Yen, J.; Liu, M. Determinants of defaults on P2P lending platforms in China. Int. Rev. Econ. Financ. 2021, 72, 334-348. [CrossRef]

43. Sorenson, O.; Stuart, T.E. Syndication networks and the spatial distribution of venture capital investments. Am. J. Sociol. 2001, 106, 1546-1588. [CrossRef]

44. Pan, F.; Zhao, S.X.B.; Wójcik, D. The rise of venture capital centres in China: A spatial and network analysis. Geoforum 2016, 75, 148-158. [CrossRef]

45. Hsu, D.H. Experienced entrepreneurial founders, organizational capital, and venture capital funding. Res. Policy 2007, 36, 722-741. [CrossRef]

46. Eddleston, K.A.; Ladge, J.J.; Mitteness, C.; Balachandra, L. Do you see what I see? Signaling effects of gender and firm characteristics on financing entrepreneurial ventures. Entrep. Theory Pract. 2016, 40, 489-514. [CrossRef]

47. Marlow, S.; Patton, D. All credit to men? Entrepreneurship, finance, and gender. Entrep. Theory Pract. 2005, 29, 717-735. [CrossRef]

48. Verheul, I.; Thurik, R. Start-up capital: “Does gender matter?". Small Bus. Econ. 2001, 16, 329-346. [CrossRef] 